\title{
PERAN KOMISI YUDISIAL DALAM MENGATASI MAFIA PERADILAN DI INDONESIA
}

\author{
Oleh :
}

\author{
Lilian G.F. Apituley
}

\begin{abstract}
Abstrak
Berbagai kalangan berpendapat bahwa terjadinya krisis di Indonesia saat ini bermuara pada ketidak-jelasan konsep yang dibangun dalam UUD 1945. Karena tidak adanya checks and balances antar alat kelengkapan organisasi Negara, selain kelemahankelemahan yang ada dalam UUD 1945. Hal ini dapat dibuktikan dengan adanya kekuasaan eksekutif sangat besar tanpa disertai oleh prinsip checks and balances yang memadai sehingga UUD 1945 bisa disebut executive heavy. Lahirnya KY dari rahim konstitusi dilatar-belakangi oleh adanya kebutuhan untuk membangun sistem pengawasan hakim yang lebih efektif dan konstruktif. Hal ini dikarenakan mekanisme pengawasan hakim oleh MA mengandung sejumlah kelemahan yaitu sangat bersifat tertutup, tidak accountable, dan cenderung mengedepankan esprit de'corps. Dan hal ini diakui jelas oleh MA. Dengan demikian bila tetap seperti ini maka proses judicial corruption tetap bertumbuh subur dalam institusi pengadilan. Faktor lain yang mendorong kehadiran KY yaitu, untuk membangun sistem seleksi hakim agung yang lebih objektif, transparan dan partisipatif. Kehadiran KY dalam struktur kekuasaan kehakiman adalah agar masyarakat dapat dilibatkan dalam proses pengangkatan, penilaian kerja, dan kemungkinan pemberhentian hakim. Hal ini dimaksudkan untuk dapat mewujudkan kebenaran dan keadilan berdasarkan Ketuhanan Yang Maha Esa, sehingga diperlukan institusi pengawasan yang independen terhadap para hakim itu sendiri
\end{abstract}

Key Words: Komisi Yudisial, Wewenang, Mafia Peradilan

\section{Pendahuluan}

Sebuah negara yang kuat (strong state), yang didukung oleh pemerintah yang kuat (strong government), tetapi mengabaikan peranan parlemen dan partisipasi masyarakat dalam proses pertumbuhan dan pemberdayaan rakyat tidak bisa dikatakan sebagai negara demokrasi. Realitas ini nampak dalam dominasi pemerintah untuk menentukan keputusan politik atau kebijaksanaan publik dalam berbagai bidang. Dominasi kekuasaan eksekutif itu didukung dengan adanya kehadiran serta peranan birokrasi dan militer yang luar biasa. Jelasnya, pemerintah telah menghegemoni, tidak saja kekuasaan negara (eksekutif, legislatif dan yudikatif), tetapi juga memonopoli kebenaran dan menjadi penafsir tunggal ideologi dan peletak pengembangan rancang-bangun kehidupan sosial 
kemasyarakatan. ${ }^{1}$ Padahal demokrasi sebagai dasar hidup bernegara memiliki arti dan nilai penting bagi masyarakat, sebab dengan demokrasi hak untuk menentukan jalannya organisasi negara dijamin. Antara lain rakyat dapat memberikan ketentuan dalam masalahmasalah pokok mengenai kehidupannya, termasuk dalam menilai kebijaksanaan negara, karena kebijaksanaan tersebut menentukan kehidupan rakyat. ${ }^{2}$

Berdasarkan penjelasan di atas maka, negara demokrasi adalah negara yang diselenggarakan berdasarkan kehendak dan kemauan rakyat atau jika dilihat dari sudut organisasi, maka hal ini berarti suatu pengorganisasian negara yang dilakukan oleh rakyat sendiri atau atas persetujuan rakyat karena kedaulatan berada di tangan rakyat. ${ }^{3}$ Hal ini sejalan dengan pendapat Presiden Abraham Lincoln tentang demokrasi: "as goverment for the people-that is, government in accordance with the people preferences." (pemerintahan untuk rakyat - yaitu, pemerintahan yang memenuhi keinginan rakyat."4

Dalam hal yang sama, Henry B. Mayo memberikan pengertian sebagai berikut.

A democratic political system is one which public policies are made one a majority basis, by representatives

\footnotetext{
${ }^{1}$ Pieris Jhon dan Baramuli Putri A. , Dewan perwakilan daerah RI: Studi, Analisis, Kritik dan Solusi Kajian Hukum dan Politik, Edisi 1. Jakarta : Pelangi cendekia 2006. hal 1

2 Deliar Noer , Pengantar Ke Pemikiran Politik, cet. 1 Jakarta : Cv Rajawali, 1983, hal. 207

${ }^{3}$ Amir Machmud, Demokrasi, Undang-Undang dan Peran Rakyat, dalam PRISMA No.8 Jakarta : LP3ES, 1984

${ }^{4}$ Lijphart, Arend. , Democracies (Patterns of majoritian and consensus government. In twentyone countries) USA : Yale University Press, 1984. hal. 1
}

subject to effective popular control at periodic elections which are conducted one the principle of political equality and under conditions of political freedom. ${ }^{5}$

(Sistem politik demokratis adalah sistem yang menunjukan bahwa kebijaksanaan umum ditentukan atas dasar mayoritas oleh wakil-wakil yang diawasi secara efektif oleh rakyat dalam pemilihan-pemilihan berkala yang didasarkan atas prinsip kesamaan politik dan diselenggarakan dalam suasana terjaminnya kebebasan politik).

Karena kegelisahan terhadap realitas tersebutlah maka diperlukan gerakan reformasi sebagai sebuah upaya perubahan kehidupan berbangsa ke arah yang lebih baik dan lebih demokratis yang dimulai dengan perbaikan konstitusi sebagai elemen dasar sistem bernegara. ${ }^{6}$

Gerakan reformasi pada pertengahan tahun 1998 telah mengantar bangsa Indonesia memasuki sebuah jaman baru yang ditandai oleh nilai-nilai yang sesungguhnya menjadi cita-cita para pendiri republik. Peristiwa reformasi ini, menjadi tongkak sejarah, dimana Indonesia memasuki fase baru dalam perjalannya sebagai suatu negara-bangsa yang merdeka dan berdaulat, yaitu menyangkut penataan berbagai bidang kehidupan ke arah yang lebih adil,

\footnotetext{
${ }^{5}$ Henry B.Mayo, An Introduction to Democratic Theory, dalam Mahfud MD, Hukum dan PilarPilar Demokrasi, Yogjakarta : Gama Media,1999,hal. 8

${ }^{6}$ Denny Indrayana, Makala : Proses Reformasi Konstitusi Transisi (Pengalaman Indonesia dan perbandingan dengan Afrika Selatan dan Thailand) Disampaikan dalam forum Experts Meeting “ Amandemen UUD 1945 ", Yogyakarta, 17-18 maret 2007
} 
demokratis, dan sejahtera. Kebutuhan akan penataan kembali berbagai aspek kehidupan bangsa ini tidak bisa dipisahkan dari munculnya degradasi kepemimpinan, kesenjangan dan ketimpangan distribusi serta alokasi sumber-sumber daya ekonomi, juga disorientasi kolektif akan arah dan tujuan berbangsa dan bernegara. Salah satu penyebab terpenting di balik kenyataan tersebut adalah pelestarian kebijakan sentralisasi dan penyeragaman politik secara berlebihan di bawah sistem otoriter selama hampir 40 tahun, sehingga membunuh segenap potensi kreativitas dan kemandirian masyarakat

Negara orde baru atau lebih sempit lagi Presiden Soeharto beserta para kroni politiknya, tidak hanya menjadi penafsir tunggal realitas masyarakat dan masyarakat menjadi nonfaktor di dalam hampir semua proses politik melainkan juga mempersonifikasikan diri secara distortif seolah-olah sebagai representasi kepentingan masyrakat. Tak mengherankan juga bahwa lembagalembaga politik pada akhirnya diorientasikan untuk pelestarian kepentingan negara yang substansinya tidak lain yaitu demi kelangsungan dan kejayaan kekuasaan Soeharto selaku penguasa tunggal Orde Baru. ${ }^{7}$

Secara politik rakyat bukan hanya kehilangan kedaulatan dan kebebasan berekspresi, melainkan juga tak pernah merasa memiliki pemerintahan karena tidak dilibatkan dalam segenap prosesnya, kecuali secara performa biasa. Di sinilah letak urgensi agenda desentralisasi, yaitu

\footnotetext{
7 Salah satu deskripsi mutakhir yang cukup baik mengenai Orde Baru lihat, R. William Liddle,"Rezim: Orde Baru", dalam Donald K. Emmerson, ed., Indonesia Beyond Soeharto : Negara, Ekonomi, Masyarkat, Transisi, Jakarta : Gramedia dan The Asia Foundation, 2001,Hal. 65121.
}

sebagai bagian dari upaya kolektifitas dalam menata kembali kehidupan bangsa ke arah yang lebih adil, demokratis, dan sejahtera. Karena itu, desentralisasi diagendakan bukan hanya dalam rangka mempertahankan keutuhan bangsa dalam keberagaman, dan bukan sekedar sebagai penyerahan wewenang pemerintahan dari pusat kepada daerah, tetapi juga mencakup agenda penyertaan masyarakat di dalam proses pemerintahan itu sendiri.

Dalam perjalan sejarah abad ke-20, pembentukan sistem politik demokrasi telah disepakati sebagai pilihan terbaik bagi negara-negara yang baru lahir menyusun proses dekolonisasi. Dalam upaya ini, peran sektor negara ternyata sangat penting, sehubungan dengan beberapa alasan yaitu antara lain adalah kenyataan rentannya kondisi masyarkat terhadap konflik serta lemahnya lembagalembaga yang berada di dalamnya yang mampu menopang kemandiriannya. Sebaliknya sektor negara relatif dengan cepat dibangkitkan dan segera muncul sebagai aktor terpenting dalam proses rehabilitasi, restrukturisasi sosial, politik dan ekonomi. Dan hasilnya sektor negara cenderung menjadi berkembang mengatasi masyarakat atau yang disebut Hamza Alavi dengan overdeveloped.

Menurut Kemal Idris, lahirnya Orde Baru yang diharapkan oleh masyarakat Indonesia untuk pembaharuan tatanan kehidupan masyarkat, berbangsa dan bernegara yang dilaksanakan berdasarkan Pancasila dan UUD 1945 secara murni dan konsekuen mendudukan fungsi dan tugas lembaga tertinggi dan tinggi negara sesuai bunyi dan makna UUD 1945. Namun, kenyataan itu tidaklah berlangsung lama karena hanya dipakai sebagai wacana untuk memenuhi ambisi pribadi dan kelompok sedangkan masyarakat ditelantarkan kepentingannya begitu saja. 
Sistem politik sentralistik-otoriter yang merupakan ciptaan Soeharto dan kroni-kroninya berhasil mempengaruhi pimpinan-pimpinan rakyat dalam lembaga-lembaga negara. Akibatnya adalah seluruh komponen kehidupan nasional menjadi rusak dan tidak memiliki akar yang kuat lagi di hati masyarakat. Fundamental demokrasi, konstitusi dan hukum tidak berjalan, sehingga tumbuhlah kekuasaan politik yang arogan. Pemerintahan sentralistik-otoriter, yang menjadikan Soeharto layaknya seorang Raja yang selalu benar ini, melahirkan budaya feodal yang sangat memungkinkan timbulnya primordialisme dan nepotisme sehingga akan mengakibatkan distorsi dan diskriminasi pada seluruh bidang kehidupan. Dan hal ini dapat mengancam keutuhan bangsa dan wilayah Negara Kesatuan Republik Indonesia.

Seperti diketahui, UUD 1945 memang secara sengaja merumuskan kedaulatan rakyat sebagai sebuah kedaulatan yang bersifat normatif. Hal tersebut dapat dilihat di dalam Pembukaan UUD 1945. Di dalam pasal 1 ayat (2) naskah asli UUD 1945, kedaulatan rakyat dapat dirumuskan secara eksplisit, bahwa "kedaulatan adalah di tangan rakyat dan dilakukan sepenuhnya oleh MPR". Konsekuensinya, rakyat akan kehilangan "kedaulatannya". Di dalam praktek kenegaraan, sering lembaga MPR mengatas-namakan rakyat untuk memilih Presiden yang sesuai dengan pilihan mayoritas rakyat Indonesia. MPR juga pernah menetapkan Tap MPR No. I/MPR/1983 untuk merubah UUD 1945, tetapi ingin tetap mempertahankan dan melaksanakan secara murni dan konsekuen. Hal ini merupakan satu di antara berbagai kenyataan yang ada dan ini jelas adalah pelecehan sistematis terhadap makna dan hakekat kedaulatan rakyat.
Rentetan permasalahan yang ada mengakibatkan reformasi amandemen konsitusi menjadi pelatuk perubahan dalam menata pola hubungan kelembagaan negara. Dan setidaknya, amandemen konstitusi telah melahiran kerangka pikir untuk beberapa hal; pertama, menghendaki adanya proses checks and balances terhadap tiga lembaga negara, yaitu legislatif, eksekutif dan yudikatif. Prinsip ini tentunya sangat penting untuk mengatasi terjadinya sentralisasi kekuasaan pada institusiinstitusi negara tertentu. Kedua, munculnya lembaga-lembaga baru (new institutions) dalam lingkungan kekuasaan kehakiman, dalam hal ini Mahkamah Konstitusi (selanjutnya disingkat MK) dan Komisi Yudisial (selanjutnya disingkat $\mathrm{KY}$ ), yang memiliki kerangka kerja yang berbeda. Bila Mahkamah Konstitusi dibentuk dengan filosofi "penjaga konstitusi", maka Komisi Yudisial dihadirkan sebagai "penjaga mafia peradilan" dengan predikat sebagai lembaga yang sifatnya auxiliary. Ketiga, memungkinkan adanya aksebilitas publik yang tinggi dalam pencapaian-pencapaian demokrasi substransif. Keempat, dimunculkan Dewan Perwakilan Daerah (DPD) sebagai perwakilan perseorangan yang dipilih berdasarkan region, walaupun belum dapat dikualifikasikan kedalam join session. Kelima, adanya transformasi sistemik antara sistem sentralistik dan desentralistik yang berimplikasi pada perubahan hubungan kelembagaan pusatdaerah.

Dalam kaitannya dengan KY maka dapat dikatakan bahwa menurut risalah persidangan-persidangan MPR yang merancang UUD 1945 tidak muncul sama sekali pemikiran untuk menjadikan KY sebagai supporting atau auxiliary organ. Tetapi yang menonjol adalah pemikiran tentang perlunya lembaga pengawas 
eksternal yang dapat menyeleksi hakim agung dan mengawasi perilaku hakim sebab lembaga pengawas internal sampai saat ini tidak efektif.

\section{Pada prinsipnya kewenangan dalam menempatkan KY tidak} dipermasalahkan secara konstitusional, mengingat di berbagai negara pun pemosisian $\mathrm{KY}$ bervariasi, tergantung kebutuhan masing-masing. Di Polandia, misalnya, Dewan Yudisial "Nasional atau the national council of the judiciary" berfungsi untuk menjaga dan melindungi kebebasan/kemandirian pengadilan dan hakim. Di Indonesia posisi KY seperti tertuang dalam UU No. 22 tahun 2004 sebagai pilihan politik dirasakan sudah cukup baik. Tetapi yang dipersoalkan adalah kewenangan MK dalam perumusan pasal-pasal tersebut dirasakan berlebihan yaitu, dengan adanya pasal-pasal yang secara teoritis dapat diartikan bahwa KY bukanlah lembaga negara utama tetapi hanyalah supporting atau auxiliary organ sehingga tidak bisa melakukan peran checks and balances. Di sisi lain MK menyatakan bahwa ketentuan kewenangan KY untuk mengawasi tingkah laku hakim tumpang tindih dengan berbagai UU yang terkait dengan kekuasaan kehakiman sehingga MK membatalkan berbagai kewenangan KY. Padahal berdasarkan konstitusi, MK hanya boleh memutuskan atau membatalkan isi UU jika bertentangan dengan UUD dan bukan bertentangan dengan UU lainnya yang sejajar. Seperti pepatah nasi telah menjadi bubur, demikian pula posisi KY saat ini. Artinya baik suka maupun tak suka, putusan MK bersifat final dan mengikat dan karenanya harus diterima dan dilaksanakan ( pasal 24C ayat (1) ). Namun tak disadari bahwa dengan MK membatalkan segala pasal pengawasan dalam UU KY, tentu saja telah membuat senyum lebar semua pelaku korupsi peradilan. ${ }^{8}$ Pertanyaan yang muncul adalah apakah yang menjadi dasar pembatasan kewenangan KY tersebut? Ataukah MK sendiri memiliki kepentingan tertentu dibalik pembatasan kewenangan tersebut? Jika kondisi hukum di Indonesia seperti ini maka apa artinya reformasi itu sendiri? Sebab menurut saya, pembatasan kewenangan ini sepertinya merupakan sebuah upaya pelanggengan mafia peradilan dan indikasi runtuhnya negara Indonesia secara perlahan namun pasti.

\section{A. ANALISIS POLITIK DAN KETATANEGARAAN SERTA IMPLIKASINYA TERHADAP PEMBENTUKAN KOMISI YUDISIAL}

\section{Analisis Politik}

Analisis politik dan ketatanegaraan khususnya terhadap lembaga peradilan negara memang terasa subjektif tetapi diharapkan dapat mengungkapkan kelemahan dan kekurangan dalam lembaga tersebut melalui reformasi peradilan sehingga proses demokrasi dapat berjalan sesuai dengan nilai-nilai moral serta dapat menjamin perlindungan terhadap kebebasan sipil-politik dan sosial-ekonomi rakyat.

Reformasi peradilan merupakan sebuah spirit dalam suatu proses demokrasi dan gerakan sosial (social movement) dalam menanggapi issue dan kepentingan masyarakat khususnya masyarakat pro-reformasi peradilan. Dalam hal ini KY sangat diperlukan untuk mengawal reformasi peradilan, khususnya yang berkenaan dengan hakim. Independensi kekuasaan kehakiman adalah hal yang prinsipil dalam suatu negara hukum yang demokratis. Karena

\footnotetext{
8 Denny Indrayana., Opini : Mahkamah Mafia Peradilan. Kompas. 28 agustus 2006
} 
tanpa kehadirannya maka tidak ada demokrasi dan negara berdasarkan hukum (demockratische rechsstaat). Independensi atau kebebasan tersebut dimaksudkan dengan tidak adanya campur tangan dari kekuasaan eksekutif dan legislatif terhadap pelaksanaan fungsi pengadilan, termasuk unsur-unsur kekuasaan kehakiman di luar sistem kekuasaan negara.

Kenyataan membuktikan bahwa independensi tanpa akuntabilitas dapat menimbulkan masalah-masalah krusial dalam negara. Karena akuntabilitas sangat dibutuhkan dalam mekanisme kontrol dalam suatu tindakan yudisial. Pengawasan sebagai wujud dari akuntabilitas dan bagian dari checks and balances dibutuhkan untuk mencapai independensi dan imparliatas peradilan. Karena tidak semua hakim memperhatikan Judicial discretion, yaitu sikap independent dan imparsial dalam memutuskan suatu perkara. Sehingga misi penting bagi reformasi peradilan tidak hanya sebatas menegakkan independensi dan impartialitas peradilan sebagai suatu prinsip dalam negara demokrasi. Tetapi juga, penting dalam membangun dan menjaga akuntabilitas dan mekanisme kontrol bagi para hakim agar peradilan tidak memunculkan abuse of power baru atau tyrani judicial. Tepai setidaknya akuntabilitas dari segi politik, sosial/public dan hukum bagi hakim baik pejabat negara maupun secara personal. ${ }^{9}$

Mafia peradilan (judicial corruption) merupakan masalah pokok yang meninbulkan bobroknya institusi peradilan, di samping permasalahan lain seperti, penumpukan perkara, managemen

\footnotetext{
${ }^{14}$ Mauro Cappeletti, 1989..dalam Arbab Paproeka., "Perubahan Bidang Politik dan Pengaruhnya Terhadap Reformasi Peradilan" dalam Bunga Rampai Komisi Yudisial dan Reformasi Peradilan. Komisi Yudisial RI, Jakarta 2007, hal 43-64
}

dan administrasi peradilan yang tidak jelas atau transparan, minimnya hakim yang berkualitas dan berintegritas, serta putusan yang janggal dan mencederai rasa keadilaan. ${ }^{10}$ Berdasarkan diagnosis, bahwa bobroknya institusi peradilan merupakan akibat dari intervensi politik yang begitu panjang yang telah mereduksi independensi dan impartialitas peradilan. Intervensi politik, terutama dari eksekutif ini tidak lepas dari praktek sistem pemerintahan otoritarian yang selalu menolak checks and balances dan tidak mengakui adanya HAM. Sedangkan lembaga peradilan hanya menjadi alat untuk menjustifikasi dan melegitimasi perilaku kekuasaan eksekutif. Perlahan tapi pasti, pengadilan akan menjadi suatu institusi yang tertutup, korup, dan tidak berwibawa.

Reformasi peradilan dimulai dengan revisi kebijakan satu atap (UU No. 14/1970) yang menempatkan urusan organisasi, administrasi dan financial menjadi urusan MA. Bersamaan dengan revisi kebijakan, seleksi hakim agung dan ketua MA yang sebelumnya sangat tertutup oleh DPR pada 2000-2003. Sekarang telah dipilih dan ditetapkan berasal dari kalangan akademisi dan praktisi hukum dan tujuannya adalah untuk mendorong perubahan di tubuh internal MA.

Namun demikian, fakta lain memperlihatkan bahwa praktek-praktek mafia peradilan masih tetap bertumbuh subur dalam lembaga peradilan, mulai dari Pengadilan Negeri (selanjutnya disingkat PN), Pengadilan Tinggi, sampai MA. Lihat saja kasus panitera pengganti dan hakim PN Jakarta Selatan yang memeras

\footnotetext{
15 Berdasarkan beberapa studi : Lev, 1990; BK Harman, 1997; KRHN-Leip, 1999; ICW, 2001, Asrun, 2004; Pompe, 2005)
} 
saksi dalam kasus korupsi PT. Jamsostek; kasus Probosutedjo yang mencoba menyuap majelis hakim di MA dengan uang milyaran rupiah.

\section{Pada Mei 2007, Transparancy} International Indonesia (TII) mengeluarkan hasil survey tentang korupsi yang terjadi di lembaga-lembaga pemerintahan. Dari survey tersebut, pengadilan menempati urutan teratas untuk inisiatif melakukan suap. Ini menandakan bahwa lembaga peradilan memang belum mengalami perubahan yang signifikan walaupun sudah ada reformasi peradilan karena masih ada krisis kepercayaan. Di pihak lain dikuatirkan bahwa MA tidak mampu menjalankan tugasnya dengan baik dan terbukti tidak efektif dalam setiap putusanputusan pengadilan karena tidak dapat memberikan rasa keadilan tetapi malah putusan bebas yang tidak wajar, terutama dalam kasus korupsi dan HAM. Faktafakta ini semakin membuat institusi peradilan terperosok dalam lubang kegelapan dan seakan-akan sulit untuk keluar.

Dalam hal menghindari dari permasalahan-permasalahan di atas, maka kalangan pemerhati hukum dan organisasi non-pemerintahan menganggap perlu dibentuknya Komisi Yudisial. Komisi ini diharapkan dapat memainkan fungsifungsi tertentu dalam sistem yang baru, khususnya rekrutmen hakim agung dan pengawasan terhadap hakim.

Komisi Yudisial lahir dan dibentuk berdasarkan konstitusi. Pasal 24b UUD 1945 menempatkan KY sebagai lembaga negara yang bersifat mandiri dan memiliki kewenangan dalam mengusulkan calon hakim serta kewenangan lain dalam rangaka menjaga dan menegakkan kehormatan, keluhuran martabat, serta perilaku hakim. Meski KY bukan pelaku kekuasaan kehakiman, namun fungsinya berkaitan dengan kekuasaan kehakiman yaitu fungsi pengawasan. UU No 22/2004 tentang KY mengatur bahwa, obyek pengawasan KY terhadap hakim meliputi hakim agung dan hakim pada badan peradilan di bawah MA serta hakim MK. Selain itu, dalam konteks pengawasan, KY dapat menerima laporan dari masyarakat yaitu laporan tentang perilaku hakim, dan memberikan usul pemberian sanksi (punishment) dan penghargaan (reward). Sehingga dapat dikatakan bahwa KY memiliki fungsi penting dalam penegakan hukum dan keadilan di Indonesia.

\section{Analisis Kewenangan MK \\ Terhadap KY}

Mahkamah konstitusi merupakan fenomena baru dalam dunia ketatanegaraan. Sesuai ketentuan UUD 1945, MK memiliki beberapa kewenangan sebagai beriku ${ }^{11}$ :

1. Menguji UU terhadap UUD;

2. Memutus sengketa kewenangan lembaga negara yang kewenangannya diberikan oleh UUD;

3. Memutus pembubaran partai politik;

4. Memutus perselisihan tentang hasil pemilihan umum;

5. Memutus pendapat DPR bahwa Presiden atau Wakil Presiden telah melakukan pelnggaran hukum berupa pengkhianatan terhadap negara, korupsi, penyuapan, tindak pidana berat lainnya, atau perbuatan tercela;

6. Memutus pendapat DPR bahwa Presiden atau Wakil telah tidak lagi memenuhi persyaratan sebagai Presiden atau Wakil Presiden.

16 Jimly Asshiddiqie., Konstitusi dan Konstitusionalisme Indonesia, cet 2, Jakarta : Konstitusi Press, 2006, hal 246-252 
Dari berbagai prespektif itu, maka sebenarnya UUD 1945 sebagai konstitusi (hukum dasar) telah mengatur hal-hal penting mengenai semua lembaga negara khususnya tentang kewenangannya. Persoalannya adalah bila yang diamanatkan oleh konstitusi itu tidak dilaksanakan dengan baik. Dan bisa saja konstitusi tidak secara jelas merumuskan ketentuan mengenai kewenangan sebuah lembaga negara. UUD 1945 sebagai konstitusi tertulis (written constitution) atau sebagai hukum yang tertinggi (Grundgesetz) yang mempunyai kekuatan mengikat melebihi UU biasa, dengan segala keterbatasannya telah mengatur fungsi-fungsi serta pembatasan kekuasaan dari semua lembaga negara, khususnya KY, MA, dan MK. Jika berpegang pada asas legalitas dan gagasan konstitusional maka semua ketentuan yang dirumuskan dalam UUD 1945 tidak dapat dihindari walaupun ketentuan tersebut dianggap tidak sempurna. Seperti yang dikatakan Lunshof (1989:7)"asas legalitas adalah asas yang dipakai untuk menjamin asasasas lainnya, antara lain asas pembatasan kekuasaan pemerintah dan HAM". Lebih lanjut dikatakan bahwa adanya pengawasan pengadilan terhadap pelaksanaan kekuasaan yang dijalankan oleh pemerintah, pemberiwewenang kepada pemerintah dan perlindungan hukum terhadap yang berkuasa.

Berkaitan dengan kewenangan KY yang termuat dalam UU No 22/2004, selanjutnya dikaitkan dengan pasca putusam MK maka ada tiga hal krusial yang menonjol, yaitu :

1. UUD 1945 telah menetapkan kewenangan $\mathrm{KY}$ sebagai lembaga negara yang mempunyai tugas dalam hal mengawasi hakim (di MA dan MK) walaupun tidak maksimal.
2. KY berdasarkan amanat UUD 1945 , berusaha melaksanakan kewenangannya walaupun diperhadapkan dengan berbagai resiko.

3. MK memutuskan bahwa kewenangan KY dalam mengawasi hakim-hakim tetapi tidak termasuk hakim MK. Karena tidak sesuai dengan pasal $24 \mathrm{~b}$ ayat (!).

Penolakan dan ketidak-setujuan mengenai pengawasan hakim agung oleh $\mathrm{KY}$ inilah yang melatarbelakangi permohonan pengujian UU RI No. 22/2004 tentang KY dan tentang pengujian UU RI No.4/2004 tentang kekuasaan kehakiman terhadap UUD RI tahun 1945 ke MK. Dan MK telah memutuskan permohonan tersebut dengan putusan MK RI No. 005/PUU-IV/2006, yang disampaikan dalam Sidang Pleno Mahkamah Konstitusi yang terbuka secara umum, pada Rabu, 23 Agustus 2006 yang berbunyi sebagai berikut : "menyatakan permohonan para pemohon dikabulkan untuk sebagian":

Menyatakan :

1. Pasal 20, yang berbunyi, "dalam melaksanakan wewenang sebagaimana dimaksud dalam pasal 13 huruf b, Komisi Yudisial mempunyai tugas melakukan pengawasan terhadap perilaku hakim dalam rangka menegakan kehormatan dan keluhuran martabat serta menjaga perilaku hakim";

2. Pasal 21, berbunyi, "untuk kepentingan kewenangan sebagaimana dimaksud dalam pasal 13 huruf b, Komisi Yudisial bertugas mengajukan usul penjatuhan sanksi terhadap hakim kepada pimpinan MA/MK"; 
3. Pasal 22 ayat (!) huruf e, yang berbunyi "dalam melaksanakan pengawasan sebagaimana dimaksud dalam pasal 20, KY membuat laporan hasil pemeriksaan dan kemudian disampaikan kepada MA/MK, serta tembusannya disampaikan kepada Presiden dan DPR";

4. Pasal 22 ayat (5), yang berbunyi: "dalam hal badan peradilan atau hakim tidak memenuhi kewajiban sebagaimana dimaksud pada ayat (4), maka MA/MK wajib memberikan penetapan berupa paksaan kepada badan peradilan untuk memberikan keterangan atau data yang diminta.";

5. Pasal 23 ayat (3), yang berbunyi, "usul penjatuhan sanksi sebagaimana dimaksud pada ayat (1) huruf b dan c diserahkan oleh Komisi Yudisial kepada MA/MK";

6. Pasal 23 ayat (5), yang berbunyi, "dalam hal pembelaan diri ditolak, usul pemberhentian hakim diajukan oleh MA/MK";

7. UU RI No 22 Tahun 2004 tentang Komisi Yudisial (Lembaga Negara RI Tahun 2004 No 89. Tambahan Lembaran Negara RI No 4415), bertentangan dengan UUD RI Tahun 1945 ;

8. UU RI No 4 Tahun 2004, tentang KY ( Lembaran Negara No 89, dan tambahan lembaran negara No 4415) tidak mempnyai kekuatan mengikat secara hukum.

Sepak terjang KY dalam melakukan pengawasan sangatlah positif karena setidaknya telah menimbulkan shock therapy di kalangan hakim. Dalam hal ini KY yang terbentuk pada 2 Agustus 2005, dengan visinya "Menjadikan Hakim sebagai Insan Pengabdi dan Penegak Keadilan", dan misinya : (1). menyiapkan hakim agung yang berakhlak mulia, jujur, berani dan kompeten; (2). melaksanakan pengawasan peradilan yang efektif, terbuka dan dapat dipercaya; (3). mengembangkan sumber daya hakim menjadi insan yang mengabdi dan menegakkan keadilan.

Namun dalam 2 tahun kinerjanya, ini bukan hal yang mudah untuk dilaksanakan. Akan tetapi KY dalam pelaksanaan tugasnya tetap mendapat simpati besar dari masyarakat.

Sayangnya, putusan MK berbicara lain dan dalam putusannya mengabulkan hampir semua permohonan. Akibatnya, KY kehilangan kekuatan dalam melakukan pengawasan terhadap hakim. Denny Indrayana, lewat rubrik opini dalam harian kompas menyatakan bahwa "Lonceng kematian berdentang kencang dan makin maraklah mafia peradilan dengan adanya putusan MK No 005/PUUIV/2006 yang menguji konstitusionalitas beberapa pasal dalam UU KY”. Lebih lanjut dinyatakan bahwa, 31 hakim sebagai pemohon pengujian, bersama para kuasa hukumnya, di antaranya: OC Kaligis, Juan Felix Tampubolon, dan Indryanto Seno Adji sedang tersenyum lebar karena hampir semua permohonan mereka dikabulkan oleh MK.

Sangat tidak wajar kalau MK menggunakan dalil ketidakpastian hukum atau kepastian hukum dalam hal membatalkan suatu peraturan perundangan. Padahal dalam konstitusi jelas diatur bahwa MK hanya boleh membatalkan UU yang bertentangan dengan UUD dan bukan bertentangan UU lainnya yang sejajar. Putusan UU KY jelas mencerminkan hakim konstitusi terjebak Conflict of interest. ${ }^{12}$ Dan ironisnya, pilihan hukum yang dijatuhakan MK nyata-nyata menumbuh-suburkan

\footnotetext{
${ }^{17}$ ibid hal ..8
} 
praktek korupsi peradilan dalam hal ini praktek mafia peradilan.

Pentingnya pengawasan hakim dari pengaruh mafia peradilan, karena dalam realitasnya mereka telah menghilangkan akses keadilan bagi masyarakat dan pencari keadilan. Oleh karena itu, pemulihan kewenangan KY untuk mengungkapkan modus opera dan upaya pemberantasan mafia peradilan adalah sangat penting dan perlu penguatan pengawasan dan peran serta masyarakat dalam mengontrol praktek peradilan. Karena praktek mafia peradilan diperkirakan akan semakin menjadi-jadi disebabkan perilaku hakim yang tidak lagi diawasi/dikontrol oleh lembaga lain $(\mathrm{KY})$, tetapi hanya diawasi sendiri oleh sesama temannya.

\section{B. IMPLIKASI PERAN KOMISI YUDISIAL DALAM MENGATASI MAFIA PERADILAN DI INDONESIA}

\section{Mafia Peradilan di Indonesia}

Mafia Peradilan (judicial corruption) adalah penyakit bangsa yang bila tidak secepatnya diatasi maka akan menjadi problem besar yang dapat menciptakan kerancuan dalam institusi negara dan menimbulkan ketidakadilan. Reformasi peradilan merupakan bagian terpenting dalam mengatasi segala bentuk ketidakadilan dalam lembaga-lembaga peradilan negara. Tak dapat disangkali bahwa peran para penegak hukum merupakan salah satu bagian penting dalam menciptakan keadilan dan kesejahteraan bagi masyarakat karena bila penegak hukum memiliki mental yang tidak bermoral dan tidak berketuhanan Yang Maha Esa maka akan mengakibatkan terciptanya pemerintahan yang tidak beradab.
Reformasi peradilan mempunyai tujuan dan tugas utama untuk menjamin dan mempertahankan prinsip-prinsip negara hukum yang demokratis. Dalam pengertian demokratis bukan hanya soal kebebasan sipil dan politik tetapi mutlak mensyaratkan rule of law. Demokrasi juga mensyaratkan adanya praktek penegakan hukum yang jelas dan tegas. Dalam hal ini hukum dipandang sebagai alat penting yang luwes dalam mencapai tujuan, yakni menciptakan suatu iklim yang menguntungkan sehingga dapat membantu kelancaran usaha-usaha pembangunan. ${ }^{13}$

Praktek mafia peradilan dapat diatasi dengan reformasi di bidang hukum dan peradilan melalui sebuah proses yang membutuhkan waktu yang lama. Karena pelaksanaannya merupakan masalah yang rumit dan kompleks serta harus dilakukan secara holistik. Perbaikan itu meliputi tahap formulasi (pembuataan peraturan perundang-undangan), tahap aplikasi (penerapan hukum) dan tahap eksekusi (penegakan hukum).

Dalam reformasi peradilan, peran hakim menjadi faktor penting dan menentukan bahwa pengadilan di Indonesia bukanlah suatu permainan (game) ${ }^{14}$ dalam mencari menang atau kalah, melainkan mencari kebenaran dan keadilan. Hal ini dikarenakan progresivitas pengadilan yang ditentukan oleh apa yang dilakukan para hakimnya. Oleh sebab itu, yang harus dilakukan pemerintah dalam mengatasi praktek mafia peradilan adalah :

1. Melakukan pembenahan struktur hukum melalui penguatan kelembagaan dengan meningkatkan profesionalisme hakim

\footnotetext{
${ }^{18}$ Satjipto Rahardjo. , Membedah Hukum

Progressif. Kompas,2006. cet 1, hal 240

19 Ibid, hal 275
} 
dan staf peradilan serta kwalitas sistem peradilan yang terbuka dan transparan, menyederhanakan sistem peradilan, meningkatkan transparansi agar peradilan dapat diakses oleh masyarakat dan memastikan bahwa hukum diterapkan dengan adil dan memihak pada kebenaran.

2. Peningkatan integritas moral dan keprofesionalan aparat penegak hukum, termasuk kepolisian RI dalam menumbuhkan kepercayaan masyarakat dengan meningkatkan kesejahteraan, dukungan sarana dan prasarana hukum, pendidikan, serta pengawasan yang efektif.

3. Dalam membuat sebuah peraturan atau kebijakan haruslah didasarkan pada hasil penafsiran yang kontekstual terhadap UUD 1945 dan menjadikannya sebagai filter dalam mengkritisi semua proses penegakan hukum di Indonesia.

\section{Komisi Yudisial yang Idealis}

Kehadiaran KY pada hakikatnya adalah untuk menjawab tuntutan masyarakat dalam penetapan prinsipprinsip demokrasi bagi penyelenggaraan pemerintahan yang akuntabel dan independen. Kiranya dapat dipahami bahwa pembentukan KY selain diarahkan untuk menciptakan sebuah lembaga pengawas dalam kekuasaan yudikatif, tetapi bermakna untuk menjaga dan menegakan kehormatan, keluhuran martabat, serta perilaku hakim.

Sayangnya, kewenangan KY untuk menjaga dan menegakkan kehormatan dan keluhuran martabat hakim telah diamputasi oleh putusan MK No: 005/PUU-IV/2006 pada tanggal 23 Agustus 2006. walaupun disadari bahwa putusan ini berlebihan (seperti yang telah dijelaskan pada bab sebelumnya) karena dalam hal ini MK secara sistematis melemahkan fungsi dan peran KY dengan cara "membonsai" 15 kewenangan KY dalam mengawasi perilaku hakim. Dan pada akhirnya praktek mafia peradilan semakin menjadi-jadi kerena tidak diawasi atau dikontrol oleh lembaga yang sebenarnya yang ditetapkan dalam konstitusi.

Dalam memaknai kehadiaran KY, berdasarkan pada UU No. 22/2004 maka dapat dirumuskan dua fungsi penting $\mathrm{KY}$ dalam upaya penegakan hukum dan keadilan di Indonesia: pertama, KY berfungsi untuk mempresentasikan kontrol publik ke dalam lembaga peradilan. Kedua, bersama-sama dengan MA dan MK, KY berperan untuk membentuk (reshaping) peradilan di Indonesia. KY diberikan tanggung jawab konstitusional untuk mengontrol kinerja dan perilaku para hakim atau dapat dikatakan KY adalah sang ujung tombak penegakan hukum di lembaga peradilan.

Agar performance KY lebih baik lagi, maka yang perlu dilakukan adalah:

1. Mendorong dan menjadikan issue/masalah KY menjadi issue publik, sehingga akan mendapat simpati yang lebih konkrit dan luas.

2. Memaksimalkan peranan jejaring yang telah ada dengan mendesentralisasikan kewenangan mengawasi hakim, khususnya pada daerah-daerah yang rawan mafia peradilan.

3. Menyiapkan perangkat-perangkat organisasi, terutama regulasi internal

\footnotetext{
20 Marwan Mas, Memulihkan Kewenangan Komisi Yudisial dengan Melibatkan Kemitraan (jejaring) di Daerah, Jakarta : Komisi Yudisial, Hal 275-285.
} 
untuk memperlanjar tugas dan menciptakan terdistorsinya proses kewenangan $\mathrm{KY}$.

4. Menyusun code of conduct yang dapat digunakan sebagai pedoman dan indikator dalam pengawasan hakim.

5. Memperkuat fungsi dan peranan KY di dalam revisi UU KY.

6. Melakukan kampanye dan pendidikan kepada publik dalam hal memerangi mafia peradilan. Dalam hal ini, meminta DPR dan Presiden agar sungguh-sungguh melakukan pemberantasan mafia peradilan sebagai upaya dalam memberantas korupsi.

Mengingat KY memiliki peranan strategis dalam mengawal reformasi peradilan, maka sudah sepatutnya peranan KY perlu diperkuat kedepan. Semoga hal ini tidak hanya menjadi sebatas harapan belaka.

\section{Penutup}

Dari uraian di atas, maka dapat disimpulkan bahwa Pembatasan kewenangan $\mathrm{KY}$ oleh MK berdasarkan putusan No. 005/PUU-IV/2006 dapat penegakan hukum yang merupakan salah satu prasyarat dalam menciptakan Negara hukum di Indonesia, sehingga Pemerintah perlu mendasari kebijakan-kebijakan politik hukumnya dengan hasil penafsiran yang benar terhadap UUD 1945 dan bukan didasarkan pada kepentingan-kepentingan tertentu.

Mengadakan Reformasi sistem peradilan di Indonesia dengan mencegah campur tangan eksekutif atau legislatif, mengembalikan kewenangan Komisi Yudisial untuk memperkuat fungsi pengawasan hakim dan memperkuat eksistensi pengadilan Tipikor. Memperkuat seleksi Hakim Agung oleh $\mathrm{KY}$, penetapan gaji yang berdasarkan pengalaman dan kemampuan, kebebasan memperolah akses informasi, proses peradilan yang harus dilakukan secara terbuka dan yang paling penting adalah Hakim Agung hasil seleksi harus memiliki ahlak dan moralitas yang baik serta lebih mengutamakan kepentingan bangsa dan Negara dari pada pribadi dan golongan.

\section{Pustaka}

Pieris Jhon dan Baramuli Putri A.., 2006, Dewan perwakilan daerah RI: Studi, Analisis, Kritik dan Solusi Kajian Hukum dan Politik, Edisi 1. Jakarta : Pelangi Cendekia.

Deliar Noer.,1983. Pengantar Ke Pemikiran Politik, cet. 1 Jakarta : Cv Rajawali.

Amir Machmud.,1984. Demokrasi, Undang-Undang dan Peran Rakyat, dalam PRISMA No.8 Jakarta : LP3ES

Lijphart, Arend.,1984. Democracies (Patterns of majoritian and consensus government. In twenty-one countries) USA : Yale University Press

Henry B.Mayo.,1999. An Introduction to Democratic Theory, dalam Mahfud MD, Hukum dan Pilar- Pilar Demokrasi, Yogjakarta : Gama Media

Denny Indrayana.,2007. Makala : Proses Reformasi Konstitusi Transisi (Pengalaman Indonesia dan perbandingan dengan Afrika Selatan dan Thailand) Disampaikan dalam forum Experts Meeting “ Amandemen UUD 1945 “, Yogyakarta.

Donald K. Emmerson, ed., 2001. Indonesia Beyond Soeharto : Negara, Ekonomi, Masyarakat, Transisi, Jakarta : Gramedia dan The Asia Foundation. 
Denny Indrayana., Opini : Mahkamah Mafia Peradilan. Kompas. 28 Agustus 2006.

Jimly Asshiddiqie. ,2006. Konstitusi dan Konstitusionalisme Indonesia, cet 2, Jakarta : Konstitusi Press.

Mauro Cappeletti, 1989., dalam Arbab Paproeka., "Perubahan Bidang Politik dan Pengaruhnya Terhadap Reformasi Peradilan" dalam Bunga Rampai Komisi Yudisial dan Reformasi Peradilan. Komisi Yudisial RI, Jakarta 2007

Satjipto Rahardjo., 2006. Membedah Hukum Progressif. Kompas. cet 1.

Marwan Mas., 2007. Memulihkan Kewenangan Komisi Yudisial dengan Melibatkan Kemitraan (jejaring) di Daerah, Jakarta : Komisi Yudisial. 